\title{
Mythos
}

Rivista di Storia delle Religioni

$10 \mid 2016$

Varia

\section{Searching for a Source of the Coptic Hemerology}

Diachronic and Synchronic Approaches

\section{Christoffer Theis}

\section{OpenEdition}

\section{Journals}

Electronic version

URL: http://journals.openedition.org/mythos/447

DOI: $10.4000 /$ mythos. 447

ISSN: 2037-7746

Publisher

Salvatore Sciascia Editore

\section{Printed version}

Date of publication: 1 December 2016

Number of pages: 61-79

ISBN: 978-88-8241-476-4

ISSN: 1972-2516

Electronic reference

Christoffer Theis, «Searching for a Source of the Coptic Hemerology », Mythos [Online], 10 | 2016,

Online since 24 September 2019, connection on 28 September 2019. URL : http://

journals.openedition.org/mythos/447 ; DOI : 10.4000/mythos.447

Mythos 


\section{Searching for a source of the Coptic hemerology. Diachronic and synchronic approaches*}

\section{Christoffer Theis}

\begin{abstract}
The article offers a study of the known Coptic calendars with favorable and unfavorable days, entitled hemerologies, and compares the given information with the information presented in earlier calendars from Egypt and Mycenaean Greece and also with later sources written in Arabic and Latin. The starting point of this study is Pap. Heidelberg Inv. Kopt. 236, a newly edited Coptic hemerology which forms the second oldest example of this type known so far. In comparison, the material clearly shows that predictions for certain days are not necessarily results of direct influences and can be seen as examples of cultural convergences.
\end{abstract}

\section{Keywords}

Coptic hemerology - Egypt - Calendars

\section{Schlüsselworte}

Koptische Hemerologie • Ägypten • Kalender

\section{Zusammenfassung}

Der vorliegende Beitrag bietet eine Studie zu den bisher bekannten koptischen Kalendern mit günstigen und ungünstigen Tagen, welche als Hemerologien bezeichnet werden, und vergleicht diese sowie die in innen vorliegenden Informationen mit früheren Kalendern aus Ägypten und der mykenischen Kultur wie auch mit späteren Quellen auf Arabisch und Latein. Den Ausgangspunkt der Studie bildet Pap. Heidelberg Inv. Kopt. 236, eine neu edierte koptische Hemerologie und bisher das zweitälteste Exemplar dieser Gattung. Im Vergleich zeigen die heute bekannten Texte klar, dass Vorhersagen für bestimmte Tage nicht zwangsläufig auf direkte Einflüsse zwischen Kulturen zurückzuführen sein müssen, sondern als Beispiele für kulturelle Gemeinsamkeiten gelten können.

\section{Introduction}

hemerology - from the Greek $\eta \dot{\mu \varepsilon \rho o \lambda o ́} \gamma \mathbf{t o v}$ "calendar" - is a calendar with a basic tendency to inform the reader about fas et nefas. Hemerologies are known from Egypt, Mycenaean Greece and Mesopotamia from the second and first millennium $\mathrm{BC}$ and also from later sources written in Coptic, Arabic and Latin. The aim of the study is to present an intercultural comparison of the type 'hemerology' and to outline the cultural convergences of the specific information, given in different texts from different cultures and periods, spanning 3000 years. On occasion of the "4 $4^{\text {th }}$ International Coptic Summer School" in Heidelberg (August 26 to September 9, 2012) I was able to edit a hitherto unpublished Coptic hemerology, now Pap. Heidelberg Inv. Kopt. 236. This papyrus is a typical example of

* This contribution was created as part of the sub-project A03 of the Collaborative Research Center 933 "Material Text Cultures. Materiality and Presence of Writing in Non-Typographic Societies", funded by the German Research Foundation (DFG) and located at the Ruprecht-Karls-University Heidelberg. 
a hemerology, a 'calendar of favorable and unfavorable days'. The ductus places it slightly later than Pap. London, British Library Or 9035 (19), making it the second oldest example of this type known so far. The papyrus contains a badly preserved fragment of a calendar of favorable and unfavorable days. The recto provides information about the twelfth and thirteenth day, while the verso contains details of days 21 through 23. Based on known parallels, the leaf was part of a larger ensemble in antiquity. This is clear from a comparison with the text of Parch. Vienna, National Library, K 1112 und 9885-9900, published by Walter Till. ${ }^{1}$ The ductus places the papyrus in the eighth century $\mathrm{AD} .{ }^{2}$ As a starting point, the Coptic hemerologies known so far will be collected and the presented information about lucky and unlucky days will be compared. In a second step, the sources will be compared with texts from other cultures, which will give insights into the construction of hemerologies in different cultures and different times. In sum, parallels of certain predictions can be seen in all of the material and can be described rather as examples for cultural convergences than as direct cultural influences.

\section{Coptic hemerologies}

translation of the text of Pap. Heidelberg Inv. Kopt. 236 shall serve as a basis for the
following comparisons with hemerologies from other cultures.

"rt. [Twelfth (day) ... A man, who ..., he will ...] and he will die through h[im]. [A wom]a[n, who] marries a man, she will get divorced and they will be ashamed. $13^{\text {th }}$ (day:) They gave birth to her ..., who he (or: their) ... is. A woman who is (on this day) conceived, she wi[ll] become (a) harlot; a man, who is born (on this day), will become a poor fellow. (The day) is not good to go [a]broad. (The day) is not good for washing your [cl]othes. Do not vouch for a man [o]r a woman. Do not give (sc. loan) [them] money, [an]d do not give (your) children to a trade. Do [no]t buy a slave or an animal. Do [no]t go to court (and) do not speak with [a] powerful man. Do not [tra]de on this day!

"vs. [...(The) $21^{\text {st }}$ (day) of the month: ... (and) she will lie with (her)] husband and she will stay! (The) $22^{\text {nd }}$ (day) of the month: [...] was born. It is good, [for undertaking] any business on it. It is good for going [to] any [pl] ace, for taking and giving, (as well as) for buying a donkey. [He who] will go and he who will get lost, they will return home! He who will be ill, will recover. Those who are conceived will live. She who will marry, wi[ll] immediately be pregnant. The $23^{\text {rd }}$ (day): [...] was born. A day that is good for buying a sla[ve], for buying and selling, to go [on] a journey that is long, to sail and to $\operatorname{tr}$ [avel] by ship, to celebrate a marriage, to make friends with the great (and) [those] who have power. It (sc. the day) is goo[d to ...] and to settle that place together with things of your greatness. Those who [will] get lost and those who will be on the road [they] will be found quickly. He who will be sick will recover an[d] a blessing (will) emanate from hi $[\mathrm{m}]$ !"

1 See Till 1936, 108-149.

2 Theis forthcoming. Cf. the ductus offered by Stegemann 1936, 11. On the problems relating to the palaeographical dating of Coptic documents see, for example, Boun'Hors 2006, 95-109; EMMEL 1993, 22-49; EMMEL 1999, 65-78; KASSER 1994, 175-184 and LAYTON 1985, 149-158. 
In his above mentioned publication, Till describes texts of this genre as a 'Mondlaufbuch' ['lunar cycle book'] that outlines the good and bad characteristics of 30 days. Since the calendars are organized in groups of 30 (lunar) days, the genre as a whole has often been described as 'Sammellunar' ['aggregative lunar calendar']. ${ }^{3}$ The Coptic parallels available today consistently deviate from the Heidelberg piece since they show more specific day omens. Hitherto, only very few examples of Coptic calendars with information about good and bad days are available; in part, these also contain instructions for farmers. The label 'farmer's calendar' for Pap. Heid. Inv. Kopt. 236 is rejected here for a simple reason, namely that the passages preserved do not deal with the natural cycle of the year, which would be relevant for a farmer. ${ }^{4}$ An example of a 'farmer's calendar' is provided by the menological Coptic-Arabic farmer's calendar published by Enno Littmann. Organized by months, this text offers descriptions of how to handle the seed and other objects relevant to farmers. ${ }^{5}$

The following list outlines the known Coptic calendars with favorable and unfavorable days in chronological order:

- A fragment from the Wādī Sarga, WS 19, now London, British Library Or 9035 (19). ${ }^{6}$ Papyrus, probably from the sixth or seventh century. It contains a few lines about the thirteenth and fourteenth day.

- Heidelberg Inv. Kopt. 236. ${ }^{7}$ Papyrus, from the eighth century.

- Two fragments of a Bohairic hemerology. ${ }^{8}$ Papyrus, written probably between the sixth and eighth century, found in Hermitage 25 in Dayr al-Naqlūn, room E. ${ }^{9}$ The pieces preserve a few scraps of information about the eleventh and twelfth day.

- Vienna, National Library, K 5506. ${ }^{10}$ Papyrus, ninth century. Only a few traces remain to identify the sixth day.

- University of Michigan Library, inv. 590. ${ }^{11}$ Parchment, late ninth century. The end of the sixth and the entire seventh day are preserved.

- Vienna, National Library, K 1112 and 9885-9900. ${ }^{12}$ Parchment, ninth or tenth century.

3 Besides the sources listed, one might also mention London, BM Cod. Egerton 2852, fol. $107 \mathrm{r}$ from the fifteenth century AD; see the partial text given by ERIKsson 1956, 11, who described this genre p. 12 as "Mondwahrsagebücher" ["lunar prophecy books"].

4 On the agricultural situation in eighth century Egypt see MülLER-WOdARG 1957, 14-78. On agriculture and its structure in Egypt in general one may refer to the somewhat dated but still useful work by HARTMANN 1923, 121-131. For an introduction to the Coptic calendar see WASSEF 1971b, 23-85.

5 See Littmann 1938, 108-113. The Arabic calendars often directly reference names of Coptic months, as in, e.g., Pellat 1986, 21, or festivals, as in Griveau 1914, 313-343. See also Varisco 1994, 72.

6 Published by Crum, Bell 1922, 50f. (no. 19). Referenced in Till 1943, 334. Translated by Wilfong 1999, 227 (= TM 108460).

7 THeis forthcoming.

8 These two pieces are going to be published by GHICA forthcoming.

9 See the preliminary excavation report by GodLEWski 1991, $49 \mathrm{f}$.

10 Published by Till 1943, 329-334; translation by WiLfong 1999, 228 (= TM 110269).

11 Published by Browne 1979, 45-57; translation by Wilfong 1999, 227. OrLandi 1991, 444 lists this papyrus under inventory number 6590, which should be corrected to 590. OrLandi also lists another text from the State Museums at Berlin, which should, with Wilfong 1999, 224, n. 34, be treated as a magical text with no connection to a calendar.

12 Published by Till 1936, 108-149. On this see also the revised and supplemented passages in Browne 1979, 60-63. Further translation in WILFONG 1999, 228-233. 
- Vienna, National Library, K 7027. ${ }^{13}$ Parchment, written in the tenth or eleventh century; contains only a single passage on the first lunar day.

- Fragment of uncertain date, now at Ann Arbor. ${ }^{14}$

- Cairo, Coptic Museum, inv.-no. 3808. ${ }^{15}$ Paper, twelfth century. The piece is from Idfū and contains information about the fifth and sixth day.

Till also mentions another source, London, British Library, Or. 4920 (2), ${ }^{16}$ which is in fact a badly preserved astrological text that deals with the sun and the moon.

The Coptic examples listed, namely Pap. Vienna, National Library, K 5506, Parch. University of Michigan Library, Inv. 590 as well as the first part of Parch. Vienna, National Library, K 1112 and 9885-9900, should be treated as hemerologies due to their textual structure, i.e., they give specific dates and the actions that are auspicious and inauspicious on these dates, as do the earlier examples Pap. Cairo, Äg. Mus. JdE 86637 and Pap. Sallier IV. Whereas these dates are spread throughout the year, Pap. London, British Library Or 9035 (19), the second part of Parch. Vienna, National Library, K 1112 and 9885-9900, Pap. Vienna, National Library, K 7027 and Papr. Cairo, Coptic Museum, inv. no. 3808 describe only a single month with thirty days, but give a relatively detailed account of every day.

If one compares the statements made in Pap. Heid. Inv. Kopt. 236 with those of the other Coptic calendars, one observes a few analogies, but the majority of the text is quite different, which suggests a difference in the underlying strands of tradition.

In general, the papyrus describes the twenty-second and twenty-third day as good (NanoYy), whereas the thirteenth is called "ungood" (NanoYy aN) for various undertakings. Comparable passages, e.g., in Parch. Vienna, National Library, K 1112, K R , 1. 2.4.9 and K $\mathrm{V}^{\circ}, 1.1 .7$ employ nanoYy $€$ instead of NanoYy $\mathrm{N}^{17}$

The warning uttered for the thirteenth day "a man, who is born (on this day), will become a poor fellow" is paralleled by day 23 in Parch. Vienna, National Library, K 9899, L V', 1. 4f.:

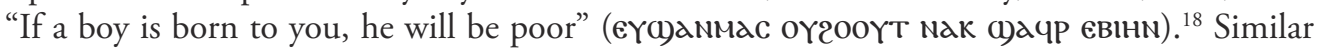
observations are made for the third day in Parch. Vienna, National Library, K 9894, G Vº 1 .

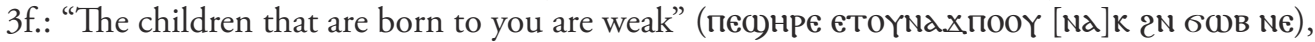
and the twenty-fifth day in Parch. Vienna, National Library, K 9895, M R, 1. 3f.: "If children

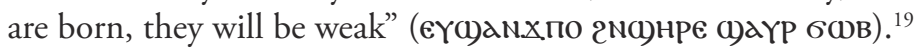

A prediction that is almost identical to the passage "A woman who is conceived (on this day), will become (a) harlot" in Pap. Heidelberg Inv. Kopt 236 is found in Parch. Vienna National Library, K 9899, L Vº 1. 3f.: "If a girl is born to you, she will become a harlot" (eүa)[an]Mac

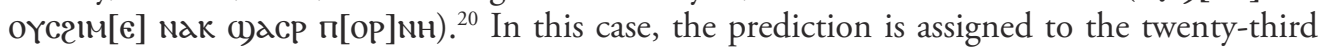

13 Noted by Till 1936, $113 \mathrm{f}$.

14 Briefly referenced by WILFONg 1999, 225.

15 Published by Abd al-Masin 1956, 1-9. Translation by Wilfong 1999, 233.

16 Cf. Till 1943, 334; published by Crum 1905, 252f. (no. 523). The older reference is Pap. Lond. Copt. 470 and Pap. London, BM 523 (= TM 86153).

17 Published by Till 1936, $127 \mathrm{f}$.

18 Ibid., 129. On євінм in general and for the parallels see VyсіснL 1983, 38.

19 Published by Till 1936, 123.

20 Ibid., 129. 
day as a bad omen. The same applies to Parch. Vienna, National Library, K 9899, L Vº 1. 6f., which also says "Do not give your child to a trade" (мпр†пєка)нрє єүтехNн), ${ }^{21}$ but gives this advice for the twenty-third day, rather than the thirteenth found in the Heidelberg papyrus.

For the twenty-third day, Parch. Vienna, National Library, K 9899, L V', 1.6 offers "Do not vouch for a man" (мпра)пторє мрбмє), ${ }^{22}$ which the Heidelberg papyrus does not mention for the twenty-third, but assigns to the thirteenth day, at least as far as the preserved part suggests. Whereas Pap. Heid. Inv. Kopt. 236 negatively associates the thirteenth day with going to court, the hemerology in Parch. Vienna, National Library, K 1112, $\mathrm{V}^{\circ}$, 1. 8f. mentions the nineteenth day as positive for going to court (євюК єпгап). ${ }^{23}$ The phrase "to buy a donkey" (є а)ळ 10$)$ for the twenty-second day is found also in Parch. Vienna, National Library, K 9885+9886, J R. 1. $x+10 .{ }^{24}$ Whereas Pap. Heid. Kopt. Inv. 236 names the twenty-second and twenty-third day as days of recovery for the sick, Parch. Vienna, National Library, K 9892, H V', 1. 2f. and K 9896 , I $\mathrm{R}^{\circ}, 1.11 \mathrm{f}$. give the sixth and ninth day, and there are also examples where this event does not occur at all. London, British Library, Or 9035 (19) describes a fourteenth day on which the sick will not recover but continue to suffer. ${ }^{25}$ Days that favor sea travel are mentioned not only for the twenty-third day in Pap. Heid. Inv. Kopt. 236, but also in Parch. Vienna, National Library, $\mathrm{K}$ 9894, $\mathrm{G} \mathrm{R}^{\circ}$, 1. 14, K 1112, $\mathrm{K} \mathrm{R}^{\circ}, 1.3$ and $\mathrm{N} \mathrm{R}^{\circ}, 1.1{ }^{26}$ These describe the second, sixteenth and twenty-ninth day as favorable for travel. Parch. Vienna, National Library, K 9896, I Rº 1. 7 describes the ninth day as suitable for a wedding (єр ()є入єєт), ${ }^{27}$ as does Pap. Heidelberg Inv. Kopt. 236 for the twenty-third, using the same phrase. Similarly, persons who have gone away shall be found on the twenty-third day in Pap. Heid. Inv. Kopt. 236 - the same is true for Parch. Vienna, National Library, K 9896, IV ${ }^{\circ}$, $1.6 f .{ }^{28}$ but the prediction is made for only one person (пєтпот семаблтч). The fact that there are also days on which fugitives are no longer found, is evident from the remark made for the seventeenth day in Parch. Vienna, National Library, K $1112, \mathrm{~K} \mathrm{R}^{\circ}$, 1. 12f. ${ }^{29}$ The text explains that "if someone flees, he will not return" (epd)[a] noya пот чNactoy an a)d en[e2]). In a similar fashion, Parch. Vienna, National Library, K 1112, K $\mathrm{V}^{\circ}, 1$. 14f. predicts for the twentieth day that "who goes abroad will never return" (пєт NaвळК [є]по)

This comparison between the predictions for the days preserved in Pap. Heid. Inv. Kopt. 236 and those made in other Coptic hemerologies clearly shows that the days are almost invariably assigned different predictions and that the auspices can change from good to bad and vice versa. The significance of this observation is unfortunately limited by the state of the source material. Most of the texts are very badly preserved and only Parch. Vienna, National Library, K 1112 and 9885-9900 is actually complete. As a result, it is at least theoretically

25 Published by Crum, Bell 1922, 50 (no. 19).

26 Published by Till 1936, 123, $127 \& 131$.

27 Ibid., 125.

28 Ibid., 126.

29 Ibid., 128.

30 Ibid., 128. 
conceivable that the Heidelberg fragment diverged from other hemerologies only in the passages preserved. The evidence gained from the remaining passages and the comparison with other hemerological calendars makes it far more likely, however, that in practice every text created its own evaluation of positives and negatives and that their allocation is unique to every text. We can note that neither of the calendars is connected to any of the others, since the days are too different from one another. The parallels that do occur can be most easily explained by treating them as incidental overlaps, since the total pool of events described in hemerologies is rather limited.

\section{Hemerologies from Pharaonic Egypt}

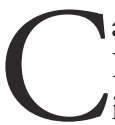

alendars that set out specific characteristics for each individual day are known from Pharaonic Egypt from the Middle Kingdom onwards. ${ }^{31}$ The earliest example so far is Pap. Kahun, XVII, 3, from the twelfth dynasty. ${ }^{32}$ The New Kingdom is generally a period of many well preserved texts. With Pap. Leiden I 346.II.6-III. $2^{33}$ and Tablette hiératique, rt. (a menology) ${ }^{34}$ from the eighteenth dynasty, and with Pap. Cairo, Eg. Mus. JdE 86637 and Pap. Sallier IV (= Pap. London, BM 10184), ${ }^{35}$ an ostracon from Dayr al-Madina, ${ }^{36}$ Pap. Turin CGT 54016 vs. ${ }^{37}$ and Ostr. Gardiner $109,{ }^{38}$ which were written during the nineteenth dynasty, a lot of texts of this genre are preserved. We can include Ostr. Turin CGT 57304, which can be dated to the New Kingdom. ${ }^{39}$ From the first millennium BC, only Pap. London, BM 10474 vs., approximately from the twenty-second to twenty-third dynasty, ${ }^{40}$ and four fragments of Pap. Golénischeff, now Moscow, Pushkin Museum, ${ }^{41}$ are known.

Generally speaking, the Coptic examples are less extensive than some of these older texts. We also have a twelfth dynasty papyrus from al-Lāhūn that labels the thirty days of a month as "good" or "bad" and is thus quite close to the later Coptic material. ${ }^{42}$ From the late period,

31 General introductions include Bács 1987, 245-251; Brunner-Traut 1970, 332-347; Spalinger 1994, $297-$ 308 and the now dated work by Wreszinski 1913, 86-100. SMith 1974, 27 mentions a demotic hemerology that seems to be unpublished as yet. Ostr. Turin CGT 57406 in Cortese 1997, 128 and López 1982, 34 \& Tf. 131 may also once have formed part of such a calendar, but not much survives beyond a couple of designations of days. In a comparable manner, the cult calendar Pap. Berlin P. 14472+Pap. Strasbourg BNU hier. 38a+Pap. Berlin P. 29065, which dates to the second or first century BC, shows notes such as "good, good" on the eleventh day that refers to the celebration of a festival, see the publication by QuACK 2012, 189-198.

32 Published by Griffith 1897, 62 \& Tf. 25 (no. 17).

33 First published by STricker 1948, 55-70. Translation in Borghouts 1978, 12-14. Analysis of the vignette by Raven i 997, 277-285. Last studied by Bommas 1999 (addendum Leitz 2002, 413-424).

34 Published by Vernus 1981, 91-93.

35 Both published by Leitz 1994.

36 Published by Malinine 1935-38, 879-883.

37 Mentioned by Roccati 1975, 245, no. 7.

38 Published by Allam 1973, 174-176 \& Tf. 40f. and Bács 1990, 46f. \& Abb. 1b.

39 Published by Posener 1951, 186f. \& Tf. 13 and López 1980, Tf. 96.

40 Published by Budge 1910, Tf. $31 \mathrm{f}$.

41 See Malinine 1935-38, 883f.

42 Published by Griffith 1897, 62 \& Tf. 15 (no. 17). Collombert 2006, 33-42 argued that hemerologies were developed already in the Old Kingdom, but the small number of parallel passages he adduces are not strong enough to support such an argument without further material. 
Pap. London BM 10474 vs. is providing evidence for an evaluation of good and bad days in the first millennium BC. ${ }^{43}$ Based on the style, the calendar can be roughly dated to the twentysecond dynasty or a little later, whereas the teachings of 'Imn-m-ip.t found on the recto date as late as the twelfth dynasty. This list of days subdivides the days of the Egyptian months into segments, with any given day apparently having three subdivisions, individually specified as $n f r$ "good" or " $h^{c}$ "obstacle". ${ }^{44}$ The same scheme is used, for example, for the fifteenth of 3.t I in Pap. Cairo JdE 86637, rt. V, 4 that is described as "good, uncertain, uncertain" (nfr chc $\left.{ }^{c} h^{c}\right)^{45}$ and the ostracon from Dayr al-Madina. ${ }^{46}$ Pap. London BM 10474 vs., and in some cases also Pap. Cairo JdE 86637, provide a similar, more accurate subdivision of the days that can no longer be observed in the Coptic period. More comparable to the Coptic material is the structure of Pap. Kahun, XVII, 3 that labels each day as $n f r$ "good", $\underline{d} w$ "bad" or as a mixture of the two. ${ }^{47}$

\section{Parallels of Coptic hemerologies: The Arabic and Latin sources}

The comparison of the statements made in the various hemerologies, but also the comparison with Pap. Vienna, National Library, K 5506, which preserves only a few days, clearly shows that in the early Islamic period of Egypt, to which the pieces are dated, several different calendars existed side by side, which also provided quite different information about their respective time periods. ${ }^{48}$ The Coptic lists of days known so far are related to earlier Egyptian texts, but also to contemporary Arabic pieces. ${ }^{49}$ In Arabic, the calendars are often called taqwim, whereas individual entries are denoted by a derivative term as tawqi' $\bar{a} t$ "events". A collection of the known examples was published by Christian Leitz. ${ }^{50}$ One of the earliest surviving versions dates to the ninth century AD and was written by Yūhannā Ibn Māsawayh ( $777-\uparrow 857$ AD). The thirty-second chapter of the astronomical work al-Tabsira fícilm an-Nuyūm by the Yemenite author al-Malik al-Ašraf Mumahhid ad-Dīn 'Umar ibn Yūsuf ibn 'Alī ibn Rasūl ibn Hārūn ibn Abī Fattāḥ al-Ġassānī al-Turkumānī may serve as an example of a menological calendar that deals in detail with the twelve months of the year and identifies a specific event for every single day within this timeframe. ${ }^{51}$ Another

43 Published by Budge 1910, Tf. 31f. A comparison of the statements made in this calendar with Pap. Cairo JdE 86637 and Pap. Sallier IV has been assembled by Porceddu et al. 2008, 327-339.

44 Comparable is the passage of the Babylonian Almanac, VII, 8 in Livingstone 1993, 99, that states that the eighth day is only half auspicious. On this text in general see Livingstone 2007, 85-100, showing beyond reasonable doubt that the almanac was used not only by specialists but by a broader audience.

45 See LeiTz 1994, 28.

46 See Malinine 1935-38, 880f.

47 Published by Grifrith 1897, 62 \& Tf. 25 (no. 17).

48 Cf. Till 1943, 332.

49 On the Arabic almanacs see the publication by PeLlat 1979, 172-185; an introduction is provided by VARISCO 1994, 6-12. For the modalities of transmission see also WASSEF 1971a, 7-45, who contrasts two Arabic calendars from the years 1866 (Era of the Martyrs 1583) and 1959 (Era of the Martyrs 1675) and identifies clear parallels to earlier Arabic works. On the information found in calendars in general see also PeLLAT 1955, 17-41.

50 Cf. Leitz 1994, 9f. Wilfong 1999, 224, n. 33 adds Munzel 1939, 665 f.

51 Translation in Varisco 1994, 23-40, Arabic text Varisco 1994, 41-60. This text is preserved in a fourteenth century AD copy that is now in Oxford, Bodleian Library, Ms. Huntington 233 (Uri 905). The text itself was 
alternative method of structuring Arabic almanacs consisted in collecting the astrological events that start at a certain point in time and incorporating these events into the descriptions of one or several weeks, as is the case, e.g., in Cambridge, Taylor-Shechter Collection, 41:103, rt. 5-21 \& vs. 5-22 $2^{52}$ and in Cambridge, Taylor-Shechter Collection, Ar. 29:183, rt. 6-21 \& vs. 6-18. ${ }^{53}$ Lunaries have survived in large numbers and have also been called "apocalypses" or "visions" of the prophet Daniel. ${ }^{54}$ Approximately contemporaneous with Pap. Heid. Kopt. Inv. 236 is Leiden, Codex 199 (catalogue 1050), a short hemerology written by Abū Ja ${ }^{c} q u \bar{b}$ ibn Ishāq al-Kindī (800-†873 AD), ${ }^{55}$ the renowned Alkindus. On the topic of choosing days for certain actions, we here find the following:

"if the moon is conjunct with the sun in trinity or sexuality, then it (sc. the day) is favorable to all business and needs." ${ }^{6}$

The specific statement that a day is good - or not - thus constitutes the intercultural link between all hemerologies.

The Latin material also contains comparable pieces. Emanuel Svenberg has collected the relevant manuscripts, all of which are from the fourteenth and fifteenth century AD. ${ }^{57}$ Of these manuscripts, especially Codex Parisinus Nouv. Acq. Lat. 1616, p. IX, fol. 10v-12r shows remarkable parallels to Pap. Heid. Inv. Kopt. 236 regarding the actions described. ${ }^{58}$ The statement "Do not vouch for a man", here made for the thirteenth day, occurs also for the twenty-third day in Parch. Vienna, National Library, K 9899, L V', 1.6 and is listed as non feneras for the sixteenth day of Codex Parisinus Nouv. Acq. Lat. 1616, p. IX, fol. 10v-12r. ${ }^{59}$ The phrase listed for the thirteenth day in Pap. Heid. Inv. Kopt. 236 "do not speak with a person of authority" is rendered in Codex Parisinus Nouv. Acq. Lat. 1616, p. IX, fol. 10v-12r as non negutiare cum aliquem, non communicis, and non facies negutium non aliquid, for the fifteenth, sixteenth and seventeenth day respectively. ${ }^{60}$ Codex Parisinus Nouv. Acq. Lat. 1616, p. IX, fol. $10 \mathrm{v}-12 \mathrm{r}$ also contains advice not to take or buy anything. For the third day, this is expressed as nec des nec accipies, for the fifth and twenty-first as nec des nec accipias. ${ }^{61} \mathrm{~A}$ prohibition to give and sell is rendered as quia qui acciperit non reddit et qui dat non receperit for the third day, as it occurs in Pap. Heid. Inv. Kopt. 236 on the thirteenth day. In Codex Parisinus Nouv. Acq. Lat. 1616, p. IX, fol. 10v-12r, the Coptic phrase N.Xı dyo $€$ Tel that characterizes the twenty-second day in Pap. Heid. Inv. Kopt. 236 is translated directly as

probably written in $1271 \mathrm{AD}$, date after Varisco 1994, 71. From Pharaonic Egypt, a menology with the tablette hiératique, rt. is known already from the eighteenth dynasty, published by Vernus 1981, 91-93

52 Published by Goldstein, Pingree i979, 155-161.

53 Published in Op. сіт., 231f. For additional examples of this kind, see the literature given in n. 58 and 62, but also Goldstein, Pingree 1983, 675-690.

54 See the compilation by Ullmann I972, 293, n. 4.

55 Published by Wiedemann 1912, $225 \mathrm{f}$.

56 Cited after $i b i d ., 225 f$.

57 See Svenberg 1963, 12-14.

58 Cf. the Latin text $i b i d ., 23-29$.

59 Cf. the Latin text ibid., 27.

60 Cf. the Latin text $i b i d ., 26 f$.

61 Cf. the Latin text ibid. $26 \& 28$. 
bona in omnia (...) dare et accipere, at least for the majority of days. ${ }^{62}$ This corresponds to the Arabic version in Leiden, Codex 199, which describes a day that favors "taking and giving". ${ }^{63}$ For most days, Codex Parisinus Nouv. Acq. Lat. 1616, p. IX, fol. 10v-12r notes that they are bona in omnia, ${ }^{64}$ which is, for all intents and purposes, identical to the Coptic nanory $2 \mathrm{~N} 20 \mathrm{y}$ NIM. The statement in Pap. Heid. Inv. Kopt. 236 that children born on the twenty-second day will live, appears for most days in Codex Parisinus Nouv. Acq. Lat. 1616, p. IX, fol. 10v-12r, rendered variously as et qui natur fuerit vitalis erit, vitalis et utilis et amabilis est, bonifacius erit and comparable formulas. ${ }^{65}$ In Codex Parisinus Nouv. Acq. Lat. 1616, p. IX, fol. 10v-12r, the sick recovers on most days, which is generally expressed as et qui incadit sanabitur. ${ }^{66}$ In the Coptic text of the Heidelberg papyrus this occurs on the twenty-second and twenty-third day. The note about days on which something will happen to fugitives has a parallel in the Latin text of London, BM Cod. 2852, fol. 108v, which reports, under the heading of a certain lunar day and a certain hour, that he who flees will find lower standing (qui fugerit in loco humili invenietur). ${ }^{67}$ One should also mention Munich, Bavarian State Library, Cod. lat. 6382, fol. $42 \mathrm{r}$ from the eleventh century, which describes the year day by day. ${ }^{68}$

If one compares the Latin text to the Coptic text under discussion here, it seems plausible that both texts ultimately derive from the same predecessors, or that a text similar to the Heidelberg piece was used as a model for Codex Parisinus Nouv. Acq. Lat. 1616, p. IX, fol. $10 \mathrm{v}-12 \mathrm{r}$. It is obvious that the comparisons offered above should not be overemphasized, but the parallels are certainly worth noting. The Latin text is also very similar to Parch. Vienna, National Library, K 1112 and 9885-9900, especially as regards the assignment of the predictions to the individual days.

\section{Sources from Rome and Greece on auspicious and inauspicious units of time}

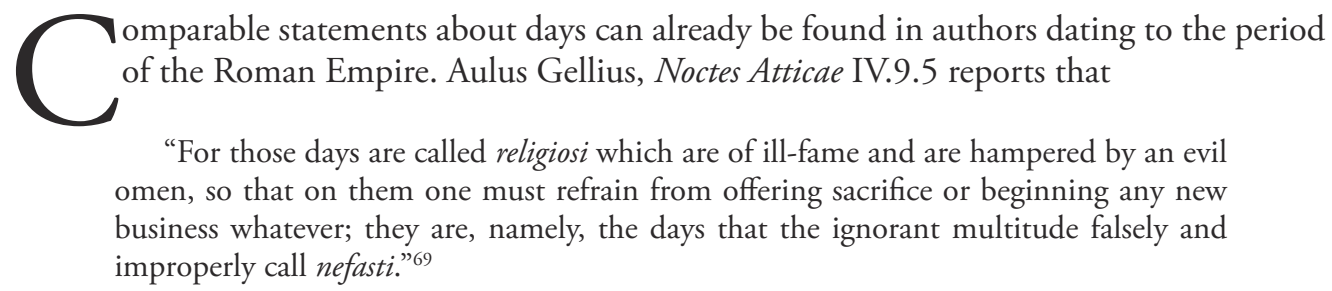

Macrobius, Sat. I.16.21 offers the similar observation that the ancestors were wary of certain days and considered them inauspicious, ${ }^{70}$ a thought that is also found in Ovid, Fast.

62 Cf. the Latin text ibid., 23-29.

63 Cited after Wiedemann 1912, 226.

64 Cf. the Latin text in Svenberg 1963, 23-29.

65 Cf. the Latin text ibid., 23-29.

66 Cf. the Latin text ibid., 23-29.

67 Latin text from ERIKsson 1956, 11.

68 Partial translation in ERIKSSON 1956, 9.

69 Cf. Marshall 1968, 174.

70 Cf. KAster 2011, 196, who also notes comparable passages in Lucius Cassius, Ann. 2 and Gnaeus Gellius, Ann. 15. 
I.57f.: omnibus istis proximus ater erit "The next after all these (sc. the ides etc.) is black." 71 The dies atri mentioned in Ovid and the dies postriduani listed in Macrobius are generally the days that follow the calends and ides. This is explicitly confirmed by Varro, Ling. VI.29, who remarks on the negative character of these segments of time:

"The days after the calends, nones and ides are called black, since on these days one should begin nothing new!"72

Vergil, Georg. I.277-286 also singles out specific days as being favorable or unfavorable for certain actions, ${ }^{73}$ when he describes the fifth as inauspicious and the seventh and ninth as auspicious. Livius, Ab Urbe Condita VI.1.12 also mentions days with auspices: Tum de diebus religiosis agitari coeptum "Then they (sc. the senate) began to argue about the religious days" ${ }^{74}$

From the Greek cultural sphere, on the other hand, hardly any texts are known that deal with auspicious days in a similarly calendric way. Two short texts that can be considered 'oracles' about good and bad days are known already from Mycenaean times. The remains of tablet Documents 207 = V 280 list six days of the month $W o-d e-w i-j o^{75}$ and have been interpreted as a report about

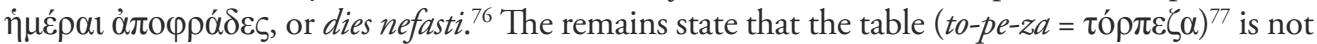
good $(o-u-k i$ te-mi = oủxì $\theta \dot{\varepsilon} \mu \mathrm{r})$ on the fourth day of the month and that the $a-p e-t i-r a_{2}^{78}$ are not good $(o-u$ te-mi $=$ ov $\theta \varepsilon \dot{\mu} \mu \varsigma)$ between the tenth and the thirteenth day. A comparable source is Documents $172=\mathrm{Kn} 02,{ }^{79}$ a kind of calendar, ten days of which - evenly divided among two different months - are still preserved, including details to which god one should sacrifice on each day. The deities named include Hermes $\left(E-m a-a_{2}\right)$, Zeus $(D i-w e)$ and Hera $(E-r a)$. The dates of these texts are relatively close to those of the most important Egyptian hemerologies Pap. Cairo JdE 86637 and Pap. Sallier IV, as well as the tablet KUB 4, $46+$ KUB 43, 1. ${ }^{80}$ Proceeding in chronological order, the next attestation is provided by Hesiod, $O p$. 765-828, who remarks on various days of the month and occasionally makes statements about the auspices of a given day, while also offering other information. ${ }^{81}$ Hesiod does not present his material in chronological order, however, and does not seem to adhere to a specific scheme of organization.

The Coptic sources generally provide statements about the 30 lunae. As numerous, usually Latin sources show, these were compiled in 'Sammellunarien', aggregative lunar calendars. The same principle is inherent in the famous peg calendar from Rome. ${ }^{82}$ Petronius, Cena Trimalchionis XXX.4 describes a work comparable to such a calendar with the words altera lunae cursum stellarumque septem imagines pictas et qui dies boni quique incommodi essent. ${ }^{83}$

71 Latin text from Frazer 1996, 6.

72 Cf. Kent 1938, 200.

73 See Erren 1985, 50-53.

74 Latin text from Conway 1958, 3.

75 Published by CHadwick 1973, 311.

76 See ibid., 311 and Meriggi 1954, 24.

77 Cf. Aura Jorro 1993, 363.

78 According to Op. cit., 79 the noun cannot be identified with certainty; CHADwICK 1973, 311 lists it as 'releasers'.

79 Published by CHADwick 1973, 286-289.

80 Published by Fincke 2009, $121 \mathrm{f}$.

81 See the translation by von SCHIRNDING 1991, 143-147. For this section see Bouché-LeCLERCQ 1899, 458-461.

82 Discussion in ERIKSSON 1956, 17-23.

83 Latin text from MüLler 2009, 24. 


\section{Summary}

$\mathrm{I}$ t has been noted that the Coptic calendars cannot be brought into agreement as regards the dates for certain predictions and that they differ also from the Latin source Codex Parisinus Nouv. Acq. Lat. 1616, p. IX, fol. 10v-12r. As a result, every Coptic calendar has to possess its own tradition, both as a text and as regards the information it contains - unless of course one wants to assume that the writer simply made up the entries up. If one compares this to early Egyptian texts, one can even observe direct contrast: As Michel Malinine has previously shown, the statements about the thirds of the day made in Pap. Sallier IV, Pap. London, BM 10474, the fragments of Pap. Golénischeff and the ostracon from Dayr al-Madina differ only in details. ${ }^{84}$ Another difference is that the Coptic material gives a relatively specific account of the positive and negative actions private individuals should or should not perform on each given day, whereas the Egyptian hemerologies known today are either mainly religious in nature or provide only curt prophecies for the day, such as "good" and/or "bad". This kind of curt prophecy is known, for example, from Pap. Kahun, XVII.3. ${ }^{85}$ The phrase that the day $n f r$ $m$ iri.t ih.t nb.t "is good for doing all things", found in Ostr. Turin CGT 57304, ${ }^{86}$ is somewhat more reminiscent of the Coptic NanOYY $2 \mathrm{~N} 20 \mathrm{Y}$ NIM, and, as was noted above, also occurs as bona in omnia in Codex Parisinus Nouv. Acq. Lat. 1616, p. IX, fol. 10v-12r. ${ }^{87}$ Ostr. Gardiner 109 also shows a rough distinction between "good" and "bad", but simultaneously includes instructions for more specific actions on certain days. ${ }^{88}$ On the fourth day, for example, sacrifices to gods should be avoided, on the twentieth no bread should be eaten in the house, on the twenty-first one should not go to court, and on the twenty-ninth arguments are to be avoided; the provisions are comparable to those made in Pap. Cairo JdE 86637, vs. XII-XIII. ${ }^{89}$ The surviving part of the ostracon from Dayr al-Madina that details the third month of Pri.t also contains predictions aimed at regular people..$^{90}$

So where did the statements made in the Coptic calendars come from? While the instructions found on the calendars often have direct parallels in other cultures, this need not suggest intercultural transfer, since the calendologies deal only with a relatively limited range of activities. These activities must necessarily recur, either due to their significance, as is the case, e.g., for marriage, the birth of children, court cases, and sea travel, or their banal omnipresence, as is the case for, e.g., washing one's clothes. Similar concerns are known also from Mesopotamia, but the more general positive or negative evaluation of days is also attested. The texts in question were created at around the same time as the ancient Egyptian and Mycenaean sources, but show predictions comparable to those found in the Coptic material. ${ }^{91}$ In the case of Astrolab. B there is, for example, a hemerology in I.1-III.46, divided into twelve

84 Cf. Malinine 1935-38, $884 f$.

85 See Griffith 1897, 62 (no. 17).

86 See Posener 1951, 187.

87 Cf. the Latin text in Svenberg 1963, 23-29.

88 See BÁcs 1990, 54-56.

89 See BAKIr 1966, $52 \mathrm{f}$.

90 Published by Malinine 1935-38, 879-883.

91 An overview of the surviving texts can be found in LivingsTone 1993, 99-107. A collection of the material is available in the edition by LIVINGSTONE 2014, which was not available to me yet. 
sections that make statements about the individual months and assign a star to each of them ${ }^{92}$ - even in the first century BC, Diodorus, Bibl. Hist. II.31 still noted the Chaldeans' exact knowledge of the moon. The thematic content of the predictions in this work is reminiscent of the Coptic and Arabic sources discussed here. A contrastive analysis of the information given about two specific actions in KUB $4.46+$ KUB 43.1 (fourteenth cent. BC), the series iqqur ipuš (thirteenth cent. BC), and the hemerology from Aššur KAR 178 (c. eleventh cent. $\mathrm{BC}$ ) clearly shows that these texts describe actions as positive or negative on the very same days, with only one exception. ${ }^{93}$ A source that focuses strongly on marriage is KUB 4. 44 Vs. 7 and KAR 179+ Vs. iii 4'-5', stating explicitly that "He should take a wife" (DAM TUK) on the twenty-sixth day. ${ }^{94}$ Going to court was of great significance already in the thirteenth century BC, with negative auspices preventing a positive outcome of the case on certain days. In the hemerology KUB 4, 42, Vs. II' 3' from Hattuša, the fourth day (DU.4.KAM) of an unknown month is characterized as follows: "For the laws[uit it is (un)favorable]" (ina D[I ŠE / NU.ŠE]). ${ }^{95}$ The same occurs for the twenty-first day in Ostr. Gardiner 109, which was mentioned above. ${ }^{96}$ Also comparable are the statement made in KUB 4, 44 Vs. 6 and KAR $179+$, Vs. iii 2'-3' for the twenty-fifth day, namely "Favorable to a judicial procedure" (DI ŠE KI.MIN), and the identical phrase found in KUB 4, 45 Vs. 10', where it characterizes an unknown day. ${ }^{97}$ The washing of clothes is also found in the hemerology KUB 4, $46+$ KUB 43, 1 , dated to the middle Hittite period. The text details for various days whether they are positive or negative for washing a garment (Vs. 1.3.5: TÚG-sú DADAG = șubassu ubbubu).$^{98} \mathrm{KAR}$ 178, VII, 3 likewise reports that the third day is suitable for this activity. ${ }^{99}$

Certain activities mentioned above and the parallels for deeds in Coptic hemerologies, mentioned in part 2, clearly show a set of predictions, which can be seen in all of the material, like washing of clothes, marriage or childbirth. But in fact even in the older material from Egypt, the dates of the predictions have significant differences, as is the case for the Coptic Hemerologies. One can detect the same activities, but they are mentioned with different dates and/or with different predictions about good or bad. Especially for the Coptic material these observations can be described rather as examples for cultural convergences than as a direct influence by another hemerology written in Coptic or another language. Direct cultural

92 Published by Weidner 1915, 85-87; briefly mentioned by Albani 1994, 225f.; compare also the source discussed by Lenormant 1878, 444, which lacks a place of origin. An introductory overview of hemerological texts in Mesopotamia is provided by LABAT 1972-75, 317-323; dated is LABAT 1939. A particular focus on magic characterizes Livingstone 1998, 59-67. On the new edition of the "standard" hemerology KAR 178 by CASABURi 2003 the reader may here be referred to the review by Livingstone 2006, 138-141.

93 See the overview compiled by FinCKe 2009, 125.

94 Published by Fincke 2010, 134.

95 Published ibid., 133.

96 See BÁcs 1990, 54-56.

97 Published in FInCKe 2010, 134 \& 143f.

98 Published by FincKe 2009, 121f. In the case of the Hittite source, scholars assume a ritual cleansing, since cleansing is often connected to 'crying out laments' (šigh šas $\hat{u})$. For the Coptic culture this cannot be presupposed since the instructions given for the day largely refer to activities of every-day life. A further parallel is provided by KAR 177, Vs. II, 25-29, in ibd. 119; a comparison between the days given for cleansing garments in KUB 4, 46 + KUB 43, 1, from the iqqur ipuš series, published by LABAT 1965, 58-203, and in the hemerology from Aššur is offered by LABAT 1965, 125.

99 See Livingstone 1993, 100. 
influences can probably be excluded due to the fact that the related material written in Latin or Arabic shows the same activities, but allocates them to different dates and/or to varying predictions - equality for a few cases can be seen as contingency due to the low percentage of occurrences.

If one considers the predictions made for the days that survive in the fragments of the Coptic material, it is obvious that pairings of prophecy and day very rarely recur. In practice, this means that one need only find and consult the "correct" calendar in order to obtain a positive omen and be willing to accept one's fate. On a theoretical level, the Coptic calendars of the early Arabic era in Egypt cannot thus have been very important, since we can certainly assume that the persons responsible were aware of the divergent statements in the calendars. Rosemarie Drenkhahn, who compared the prophecies made in Pharaonic hemerologies with the travels and work days attested at Dayr al-Madina, has drawn similar conclusions. ${ }^{100}$ Her study showed that the prophecies made about individual days had no influence on the passage of life in this settlement, situated near Thebes on the west bank of the Nile.

In early work on Coptic calendars - which should not, as has been pointed out, be treated as mere 'rural practice' due to the diversity of their themes - ${ }^{101}$ their roots were usually sought in the Greek-speaking area or in Greek texts - mainly because the chronological gap between the Pharaonic hemerologies and the known Coptic texts seemed too large. A closer look at the tradition has shown that there is no Greek source comparable to the two main Coptic examples, Parch. Vienna, National Library, K 1112 and 9885-9900, and Pap. Heid. Inv. Kopt. 236. The existing material is in fact mostly Mycenaean, which is just as remote as Pap. Cairo JdE 86637 and Pap. Sallier IV. The only other relevant statement is found in Hesiod's remarks on specific days in Opera et Dies. It has also emerged that the Pharaonic hemerologies deal almost exclusively with concerns absent from the Coptic material. However, even this brief survey has been able to show that there are numerous parallels to Mesopotamian hemerologies. One should thus consider whether these themes might not have been introduced from Mesopotamia. This transfer would have been conducted via intermediary texts, probably in Greek, that transported this knowledge from East to West.

Much more enlightening are the statements made by ancient, mostly Latin authors of the Roman Empire, since they attest the existence of at least some form of hemerology for the imperial period. It is worth quoting here a statement made in the lay astrological treatise London, BM, Cod. Sloan 3124, fol. 23r. The codex mentions sources that are firmly located in the oriental cultural sphere by means of phrases such as sicut Egiptii scribunt and Babiloniam fames magna erit. ${ }^{102}$ Even though the Codex Sloan is dated only to the fifteenth century, the

100 See Drenkhahn 1972, 85-94.

$101 \mathrm{KAI} 182$ can here be adduced as an example of a farmer's calendar from a different cultural sphere. This so-called calendar of Gèzèr, dated to the tenth century BC, lists agricultural activities for each of the twelve months, starting with the autumnal olive harvest.

102 Latin text in ErIKsson 1956, 9. Compare only the statement of Cassius Dio, Historia Romana XXXVII.18, that "the custom to name the days after the seven planets was established by the Egyptians". A short time later, Tertullian, Ieiun. 2 calls the day feria, see the text in Reifferscheid, Wissowa 1890, 275. Bar-daișan, Liber Legum Regionum 25 in NAU 1907, 581 speaks out against Babylonian and Egyptian influence on western astrology by saying the following: Legi libros astrologiae sed nescio quinam sint e Babyloniis et quinam ad Aegyptios pertineant. On this form of cross-cultural influence see BoLL 1950, 268f. \& $384 \mathrm{f}$. 
topics it discusses make it safe to say that it derives from much older documents. Already Carl Bezold and Franz Boll were able to show that Greek treatises could even draw on Babylonian sources. ${ }^{103}$ Even Synesios of Cyrene, who wrote his Aegyptii sive de providentia around 400 AD, mentions inauspicious days around the time of the festivals of Osiris, which he describes as the days of the "sacred tears" (I.16). ${ }^{104}$ I close with a quote from Vergil, Georg. I.277sq., who characterizes evaluations of days based on the moon in the following way:

Ipsa dies alios alio dedit ordine luna felicis operum

"The Moon herself has set certain days as variously auspicious for work." 105

Christoffer Theis

Ruprecht-Karls-Universität Heidelberg

Ägyptologisches Institut

Marstallhof 4

69117 Heidelberg, Deutschland

Christoffer_Theis@web.de

\section{Bibliography}

ABD AL-MasiH 1956

Y. Abd al-Masih, "A fragmentary farmer's almanac",

Les cahiers coptes 10 (1956), 1-9.

Albani 1994

M. Albani, Astronomie und Schöpfungsglaube. Untersuchungen zum Astronomischen Henochbuch, Wissenschaftliche Monographien zum Alten und Neuen Testament 68, Neukirchen-Vluyn 1994.

Allam 1973

S. Allam, Hieratische Ostraka und Papyri aus der Ramessidenzeit, Urkunden zum Rechtsleben im Alten Ägypten I, Tübingen 1973.

Aura Jorro 1993

F. Aura Jorro, Diccionario micénico, Madrid 1993.

BÁcs 1987

T. A. Bács, «Prolegomena to the Study of Calendars of Lucky and Unlucky Days», in A. Roccati, A. Siliotti (eds.), La Magia in Egitto ai Tempi dei Faraoni. Atti convegno internazionale di Studi Milano 29-31 Ottobre 1985, Mailand 1987, 245-256.

BÁCs 1990

T. A. BÁcs, "Two Calendars of Lucky and Unlucky Days», Studien zur Altägyptischen Kultur 17 (1990), 41-64.
BAKIR 1966

A. el-Mohsen Bakir, The Cairo Calendar No. 86637, Cairo 1966.

BLAU 1898

L. Blau, Das altjüdische Zauberwesen, Strassburg 1898.

Bezold, Boll 1911

C. Bezold, F. Boll, Reflexe astrologischer Keilinschriften bei griechischen Schriftstellern, Sitzungsberichte der Heidelberger Akademie der Wissenschaften 1911, Phil.-Hist. Klasse 7, Heidelberg 1911.

BOLL 1950

F. Boll, Kleine Schriften zur Sternkunde des Altertums, ed. V. Stegemann, Leipzig 1950.

VON BOMHARD 2000

A.-S. von Bomhard, "Ägyptische Zeitmessung: Die Theorie des gleitenden Kalenders", Zeitschrift für Ägyptische Sprache und Altertumskunde 127 (2000), 14-26.

VON BOMHARD 2008

A.-S. von Bomhard, The Naos of the Decades from the Observation of the Sky to Mythology and Astrology, Geoarchaeology: Underwater Archaeology in the Canopic Region in Egypt, Oxford Centre for Maritime Archaeology, Monograph 3, Oxford 2008.

103 See Bezold, Boll 1911.

104 See the Greek text in Krabinger 1835, 30. On this story see Schmitt 2001, 304-358. If these days are directly related to the moon, one must ask whether this might be linked to the attested nature of the god; see the references collected by DerCHAIN 1962, 44-46.

105 Latin text from ERren 1985, 50. 
Bommas 1999

M. Bommas, Die Mythisierung der Zeit. Die beiden Bücher über die altägyptischen Schalttage des magischen pLeiden I 346, Göttinger Orientforschung IV/37, Wiesbaden 1999.

Borghouts 1978

J. B. Borghouts, Ancient Egyptian Magical Texts, Leiden 1978 .

BouchÉ-LeClercQ 1899

A. Bouché-Leclercq, L'Astrologie Grecque, Paris 1899.

Boud'HORs 2006

A. Boud'hors, "Paléographie et codicologie coptes: progrès et perspectives (1996-2004)", in A. Boud'hors, D. Vaillancourt (eds.), Huitième Congrès international d'Études coptes. Paris, 28 juin-3 juillet 2004, Cahiers de la bibliothèque copte 15, Paris 2006, 95-109.

BROWNe 1979

G.M. Browne, Michigan Coptic Texts, Papyrologica Castroctaviana, Barcelona 1979.

BRUnNER-Traut 1970

E. Brunner-Traut, "Mythos im Alltag», Antaios 12 (1970), 332-347.

Budge 1910

E.A.W. Budge, Facsimiles of Egyptian Hieratic Papyri in the British Museum, London 1910.

CARY 2001

E. Cary, Dio Cassius - Roman History, Books XXXVI$X L$, London $2001^{6}$.

Casaburi 2003

M. C. Casaburi, Ūmē ôābūti "I giorni favorevoli", History of the Ancient Near East Studies 8, Padua 2003.

Chadwick 1973

J. Chadwick, Documents in Mycenaean Greek. First Edition by Michael Ventris and John Chadwick, Cambridge $1973^{2}$.

Collombert 2006

$\mathrm{Ph}$. Collombert, "Un étrange anthroponyme de l'Ancien Empire: "Il/Elle mourra par le crocodile" (?)», Göttinger Miszellen 209 (2006), 33-42.

CONWAY 1958

R.S. Conway, Titi Livi - Ab Urbe Condita, 5 vols., Oxford $1958^{5}$.

Cortese 1997

V. Cortese, "Le materie "scientifiche" ", in A. M. Donadoni Roveri (ed.), La scuola nell'antico Egitto, Turin 1997, 117-136.
Crum 1905

W.E. Crum, Catalogue of the Coptic Manuscripts in the British Museum, London 1905.

Crum, Bell 1922

W.E. Crum, H.I. Bell, Wadi Sarga. Coptic and Greek Texts from the Excavations undertaken by the Byzantine Research Account, Coptica 3, Hauniae 1922.

Demichelis 1998

S. Demichelis, «Papiri calendariali del Museo Egizio di Torino", Vicino Oriente 11 (1998), 37-65.

DEPUYDT 1997

L. Depuydt, Civil Calendar and Lunar Calendar in Ancient Egypt, Orientalia Lovaniensia Analecta 77, Leuven 1997.

Derchain 1962

Ph. Derchain, Mythes et dieux lunaires en Égypte, Sources orientales 5, Paris 1962.

DrenkHAHN 1972

R. Drenkhahn, "Zur Anwendung der 'Tagewählkalender'", Mitteilungen des Deutschen Archäologischen Instituts, Abteilung Kairo 28 (1972), 85-94.

EMMEL 1993

St. Emmel, «Recent Progress in Coptic Codicology and Paleography (1988-1992)", in T. Orlandi, D.W. Johnson (eds.), Acts of the Fifth International Congress of Coptic Studies, Washington, 12-15 August, 1992, 2 vols., Rome 1993, I, 22-49.

EMMEL 1999

St. Emmel, «Recent Progress in Coptic Codicology and Paleography (1992-1996)", in St. Emmel et al. (eds.), Ägypten und Nubien in spätantiker und christlicher Zeit. Akten des 6. Internationalen Koptologenkongresses. Münster, 20.-26. Juli 1996, 2 vols., Wiesbaden 1999, II, 65-78.

ERIKSSON 1956

S. Eriksson, Wochentagsgötter, Mond und Tierkreis. Laienastrologie in der römischen Kaiserzeit, Studia Graeca et Latina Gothoburgensia 3, Göteborg 1956.

ERren 1985

M. Erren (ed.), P. Vergilius Maro - Georgica, 2 vols., Heidelberg 1985.

FINCKE 2009

J.C. Fincke, "Zu den akkadischen Hemerologien aus Hattuša (CTH 546), Teil 1. Eine Hemerologie für das „Rufen von Klagen“ (ŠIGÛ ŠASÛ) und das „Reinigen seines Gewandes" (ȘUBĀT-SU UBBUBU): KUB 4, 46 (+) KUB 43, 1», Journal of Cuneiform Studies 61 (2009), 111-125. 
FINCKE 2010

J.C. Fincke, « $\mathrm{Zu}$ den akkadischen Hemerologien aus Hattuša (CTH 546), Teil II: Die „Opferbrot-Hemerologie“", Journal of Cuneiform Studies 62 (2010), 127-45.

FraZer 1996

J.G. Frazer (ed.), Ovid, Fasti, London $1996^{3}$.

GHICA forthcoming

V. Ghica, "Two Newcomers in the B5 Family: The Naqlūn Kalandologia», in: A. Camplani, P. Buzi (eds.), Acts of the 10th International Congress of Coptic Studies (forthcoming).

GODLEWSKI 1991

W. Godlewski, "Archaeological Research in Naqlun in 1991", Polish Archaeology in the Mediterranean 3 (1991), 49-56.

Goldstein, Pingree 1979

B.R. Goldstein, D. Pingree, "Astrological Almanacs from the Cairo Geniza, Part I", Journal of Near Eastern Studies 38 (1979), 153-175.

Goldstein, Pingree 1983

B.R. Goldstein, D. Pingree, "Additional Astrological Almanacs from the Cairo Geniza», Journal of the American Oriental Society 103 (1983), 673-690.

Griffith 1897

F. Ll. Griffith, The Petrie Papyri. Hieratic Papyri from Kahun and Gurob (Principally of the Middle Kingdom), London 1897.

Griffith 1970

J.G. Griffith, Plutarch's De Iside et Osiride, Cambridge 1970 .

Griveau 1914

R. Griveau, "Les fêtes des Coptes par al-Maqrîzî», Patrologia orientalis 10 (1914), 313-343.

HARTMANN 1923

F. Hartmann, L'agriculture dans l'ancienne Égypte, Paris 1923.

Kasser 1991

R. Kasser, s.v. Paleography, in A.P. Atiya (ed.), The Coptic Encyclopedia, Vol. VIII, New York 1991, 175-184.

Kaster 2011

R.A. Kaster, Macrobius - Saturnalia, 3 vols., London 2011.

Kent 1938

R.G. Kent, Varro - On the Latin Language, London 1938.

Krabinger 1835

J.G. Krabinger, Synesios des Kyrenaeers Aegyptische Erzählungen über die Vorsehung, Sulzbach 1835.
LABAT 1939

R. Labat, Hémérologies et ménologies d'Assur, Études d'Assyriologie 1, Paris 1939.

LABAT 1965

R. Labat, Un calendrier babylonien

des travaux des signes et des mois (Séries iqqur îpuš), Paris 1965 .

LABAT 1972-75

R. Labat, s.v. Hemerologien, in D. O. Edzard et al. (ed.), RLA IV, Berlin 1972-1975, 317-323.

Layton 1985

B. Layton, "Towards a New Coptic Palaeography», in T. Orlandi. F. Wisse (eds.), Acts of the Second International Congress of Coptic Studies. Roma, 22-26 September 1980, Rom 1985, 149-158.

LEITZ 1994

C. Leitz, Tagewählerei. Das Buch H\#t nHH pH.wy Dt und verwandte Texte, Ägyptologische Abhandlungen 55, Wiesbaden 1994.

LEITZ 2002

C. Leitz, "Rezension zu Martin Bommas, die Mythisierung der Zeit. Die beiden Bücher über die altägyptischen Schalttage des magischen pLeiden I 346, GOF IV/37, Wiesbaden 1999", Lingua Aegyptia 10 (2002), 413-424.

LeITZ 2010

C. Leitz, "Das dem Naos der Dekaden zugrundeliegende kalendarische System», in D. Robinson, A. Wilson (eds.), Alexandria and the north-western Delta. Joint Conference proceedings of Alexandria: City and Harbour (Oxford 2004) and the Trade and Topography of Egypt's north-west Delta, 8th century BC to 8th century AD (Berlin 2006), Oxford 2010, 183-189.

LENORMANT 1878

F. Lenormant, Die Magie und Wahrsagekunst der Chaldäer, 2 Bde., Jena 1878.

LitTMANN 1938

E. Littmann, «Ein koptisch-arabischer Bauernkalender", in R. Aвramowski (ed.), In Piam Memoriam Alexander von Bulmerincq. Gedenkschrift zum 5. Juni 1938, dem siebzigsten Geburtstage des am 29. März 1938 Entschlafenen dargebracht von einem Kreise von Freunden und Kollegen, Abhandlungen der HerderGesellschaft und des Herder-Instituts zu Riga 6/3, Riga 1938, 108-116.

Livingstone 1993

A. Livingstone, "The Case of the Hemerologies: Official Cult, Learned Formulation and Popular Practice», in E. Matsushima (ed.), Official Cult and Popular Religion in the Ancient Near East. Papers of the First 
Colloquium on the Ancient Near East - The City and its Life held at the Middle Eastern Culture Center in Japan (Mitaka, Tokyo), March 20-22, 1992, Heidelberg 1993, 97-113.

LivingSTONE 1998

A. Livingstone, "The Use of Magic in the Assyrian and Babylonian Hemerologies and Menologies», Stdui epigrafici e linguistici sul Vicino Oriente antico 15 (1998), 59-67.

LivingSTONE 2006

A. Livingstone, "Rezension zu Maria C. Casaburi, Ūmē țābūti "I giorni favorevoli", History of the Ancient Near East Studies 8, Padova 2003", Zeitschrift für Assyriologie 96 (2006), 138-141.

Livingstone 2007

A. Livingstone, "The Babylonian Almanac: A Text for Specialists?», in: B. Groneberg. H. Spieckermann (eds.), Die Welt der Götterbilder, Beihefte ZAW 376, Berlin 2007, 85-101.

Livingstone 2014

A. Livingstone, Hemerologies of Assyrian and Babylonian Scholars, Cornell University Studies in Assyriology and Sumerology, Bethesda, Maryland 2014.

LóPEz 1980

J. López, Ostraca ieratici, N. 57093-57319, Catalogo del Museo Egizio di Torino III, 2, Milan 1980.

LÓPEZ 1982

J. López, Ostraca ieratici, N. 57320-57449, Catalogo del Museo Egizio di Torino III, 3, Milan 1982.

Malinine 1935-38

M. Malinine, «Nouveaux fragments du calendrier égyptien des jours fastes et néfastes», in Mélanges Maspero I, Mémoires publiés par les membres de l'Institut francais d'archéologie orientale du Caire 66, Cairo 1935-38, 879-899.

Marshall 1968

P.K. Marshall, A. Gellii - Noctes Atticae, recognovit brevique adnotatione critica instruxit, Oxford 1968.

Meriggi 1954

P. Meriggi, «Das Minoische B nach Ventris’ Entzifferung», Glotta 34 (1954), 12-37.

Migne 1878

J.-P. Migne, Patrologiae cursus completus seu bibliotheca universalis, integra, uniformis, commoda, oeconomica omnium ss. patrum, doctorum scriptorumque ecclesiasticorum, Paris 1878 .

MÜLLER 2009

K. Müller, Petronius - Satyricon Reliquiae, Bibliotheca Teubneriana 1257, Berlin 2009.
MÜller-Wodarg 1957

D. Müller-Wodarg, «Die Landwirtschaft Ägyptens in der frühen Abbāsidenzeit 750-969 n.Chr. (132-358 d.H.) (1. Fortsetzung)", Der Islam 32/3 (1957), $14-78$.

MunZel 1939

K. Munzel, «Zum koptisch-arabischen Bauernkalender», Orientalische Literaturzeitschrift 42 (1939), 665-666.

$\mathrm{NAU} 1907$

F. Nau, «Bardesanes - Liber Legum Regionum cuius Textum Syriacum Vocalium Signis Instruxit, Latine vertit", in R. Graffin (ed.), Patrologia Syriaca I/2, Paris 1907, 491-657.

OrLANDi 1991

T. Orlandi, s.v. Calendologia, in A.P. Atrya (ed.), The Coptic Encyclopedia, Volume 2, New York 1991, 444-445.

PARKer 1950

R.A. Parker, The Calendars of Ancient Egypt, Chicago 1950 .

Pellat 1955

C. Pellat, «Dictons rimes, anwā' et mansions lunaires chez les Arabes», Arabica 2 (1955), 17-41.

Pellat 1979

C. Pellat, "Le 'calendrier agricole' de Qalqašandī", Annales Islamologiques 15 (1979), 165-85.

Pellat 1986

C. Pellat, Cinq calendriers égyptiens, Textes arabes et études islamiques 26, Cairo 1986.

Porceddu, Jetsu, Markkanen, Toivari-Vittala 2008 S. Porceddu, L. Jetsu, T. Markkanen, J. Toivari-Viitala, "Evidence of Periodicity in Ancient Egyptian Calendars of Lucky and Unlucky Days», Cambridge Archaeological Journal 18 (2008), 327-339.

Posener 1951

G. Posener, «Ostraca inédits du Musée de Turin (Recherches Littéraires III)", Revue d'Égyptologie 8 (1951), 171-189.

QUACK 2002

J.F. Quack, "Zwischen Sonne und Mond - Zeitberechnung im Alten Ägypten", in H. FALK (ed.), Vom Herrscher zur Dynastie. Zum Wesen kontinuierlicher Zeitrechnung in Antike und Gegenwart, Vergleichende Studien zu Antike und Orient 1, Bremen 2002, 27-67.

QUACK 2012

J.F. Quack, «Reste eines Kultkalenders (Pap. Berlin P. 14472 + Pap. Strasbourg BNU hier. 38 a und Pap. 
Berlin P. 29065)», in V. M. Lepper (ed.), Forschung in der Papyrussammlung. Eine Festgabe für das Neue Museum, Ägyptische und Orientalische Papyri und Handschriften des Ägyptischen Museums und Papyrussammlung Berlin 1, Berlin 2012, 189-206.

RAVEN 1997

M.J. Raven, "Charms for Protection during the Epagomenal Days», in J. van Dijk (ed.), Essays on Ancient Egypt in Honour of Herman Te Velde, Egyptological Memoirs 1, Groningen 1997, 275-291.

Reifferscheid, Wissowa, 1890

A. Reifferscheid, G. Wissowa, Tertullian - Opera, Scriptorum Ecclesiasticarum Latinarum 20, Praguel Leipzig 1890.

\section{RocCATI 1975}

A. Roccati, «Scavi nel Museo di Torino, VII: Tra I papiri Torinesi», Oriens Antiquus 14 (1975), 243-253.

Sснмітт 2001

T. Schmitt, Die Bekehrung des Synesios von Kyrene. Politik und Philosophie, Hof und Provinz als Handlungsräume eines Aristokraten bis zu seiner Wahl zum Metropoliten von Ptolemaïs, Munich 2001.

vON SCHIRNDING 1991

A. von Schirnding (ed.), Hesiod, Theogonie: Werke und Tage, Munich 1991.

SмIтH 1974

H. P. Smith, «La mère d'Apis: Fouilles récentes de l'Égypt. Exploration Society à Saqqara-Nord", Bulletin de l'Institut Français d'Égyptologie 70/71 (1974), 11-27.

Spalinger 1994

A.J. Spalinger, "Calendars: Real and Ideal», in B. M. Bryan, D. Lorton (eds.), Essays in Egyptology in Honor of Hans Goedicke, San Antonio, Texas 1994, 297-308.

SPALINGER 1995

A.J. Spalinger, "Notes on the Ancient Egyptian Calendars", Orientalia 64 (1995), 17-35.

SPALINGER 2002

A.J. Spalinger, "Ancient Egyptian Calendars: How Many Were There?», Journal of the American Research Center in Egypt 39 (2002), 241-250.

Stegemann 1936

V. Stegemann, Koptische Paläographie. 25 Tafeln zur Veranschaulichung der Schreibstile koptischer Schriftdenkmäler auf Papyrus, Pergament und Papier für die Zeit des III.-XIV. Jahrhunderts. Mit einem Versuch einer Stilgeschichte der koptischen Schrift, Quellen und Studien zur Geschichte und Kultur des Altertums und des Mittelalters 1, Heidelberg 1936.
STRICKER 1948

B.H. Stricker, «Spreuken tot beveiliging gedurende de schrikkeldagen, naar Pap. I 346", Oudheidkundige Mededelingen uit het Rijksmuseum van Oudheiden te Leiden 29 (1948), 55-70.

Svenberg 1963

E. Svenberg, Lunaria et Zodiologia Latina edidit et commentario philologico instruxit, Studia Graeca et Latina Gothoburgensia XVI, Göteburg 1963.

$\overline{\text { THEIS FORTHCOMING }}$

C. Theis, «Papyrus Heidelberg Inv. Kopt. 236. Fragment einer Tagewählerei», in A. BouD'HORS ET AL. (eds.), Coptica Palatina. Koptische Texte, bearbeitet auf der 4. Internationalen Sommerschule für Koptische Papyrologie (Heidelberg, 26. August - 8. September 2012), Veröffentlichungen aus der Heidelberger Papyrus-Sammlung, Heidelberg 2014 (forthcoming).

TiLl 1936

W. Till, «Eine koptische Bauernpraktik», Mitteilungen des Deutschen Archäologischen Instituts, Abteilung Kairo 6 (1936), 108-149.

TILl 1943

W. Till, «Bemerkungen zu koptischen Textausgaben. 7-8», Orientalia 12 (1943), 328-337.

ULLMANN 1972

M. Ullmann, Die Natur- und Geheimwissenschaften im Islam, Handbuch der Orientalistik I/VI, 2, Leiden 1972.

VARISCO 1994

D.M. Varisco, Medieval Agriculture and Islamic Studies. The Almanac of a Yemeni Sultan, Seattle/ London 1994.

Vernus 1981

P. Vernus, «Omina calendériques et comptabilité d'offrandes sur une Tablette Hiératique de la XVIII ${ }^{e}$ dynastie», Revue d'Égyptologie 33 (1981), 89-124.

VYCICHL 1983

W. Vycichl, Dictionnaire étymologique de la langue copte, Leuven 1983.

WASSEF 1971a

C.W. Wassef, «Le calendrier copte, de l'antiquité à nos jours", Journal of Near Eastern Studies 30 (1971), $1-48$.

WASSEF 1971b

C.W. Wassef, Pratiques rituelles et alimentaires des Coptes, Bibliothéque d'Étude Copte 9, Cairo 1971.

WEIDNER 1915

E.F. Weidner, Handbuch der babylonischen Astronomie, Assyriologische Bibliothek 23, Leipzig 1915. 
WEISS 1875

G.F. Weiß, Die attischen Nächte, 2 vols., Darmstadt 1875 (reprinted 1981).

WiEdEMANN 1912

E. Wiedemann, «Über einen astrologischen Traktat von al Kindi», Archiv für die Geschichte der Naturwissenschaften und der Technik 3 (1912), 224-226.

WILFONG 1999

T.G. Wilfong, «Agriculture among the Christian Po- pulation of Early Islamic Egypt: Practice and Theory», in A. K. Bowman, E. Rogan (eds.), Agriculture in Egypt. From Pharaonic to modern Times, Proceedings of the British Academy 96, Oxford 1999, 217-235.

\section{WRESZINSKI 1913}

W. Wreszinski, "Tagewählerei im alten Ägypten», Archiv für Religionswissenschaft 16 (1913), 86-100. 